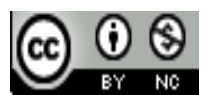

Jurnal Pendidikan Dasar Indonesia is licensed under

A Creative Commons Attribution-Non Commercial 4.0 International License

\title{
Pendidikan Mitigasi Bencana Di Sekolah Dasar (SEBUAH KaJIAN ANALISIS ETNOPEDAGOGI)
}

\author{
Putu Eka Suarmika ${ }^{1)}$, Erdi Guna Utama ${ }^{2)}$ \\ ${ }^{1)}$ PGSD Universitas Abdurachman Saleh Situbondo, Jawa Timur \\ E-mail: eka_suarmika@yahoo.com \\ ${ }^{2)}$ PGSD STKIP Singkawang, Kalimantan Barat \\ E-mail: erdi.guna.utama@gmail.com
}

\begin{abstract}
Abstrak. Dalam etnopedagogi, unsur utama adalah kearifan lokal masyarakat yang diintegrasikan ke dalam pendididikan. Kearifan lokal atau local wisdom dapat dipahami sebagai suatu pemahaman kolektif, pengetahuan, dan kebijaksanaan yang mempengaruhi suatu keputusan penyelesaian atau penanggulangan suatu masalah kehidupan. Pendidikan mitigasi bencana berbasis kearifan lokal dapat dilaksanakan pada Kurikulum 2013 dengan (1) mengidentifikasi kearifan lokal dalam mitigasi bencana dan (2) mengintegrasikan dalam pembelajaran. Sejak usia dini anak didekatkan dengan bencana dan menjaga serta memperlakukan lingkungan dengan baik, maka akan membentuk anak yang tangguh dalam menghadapi bencana dan mencintai lingkungan untuk kehidupan yang berkelanjutan.
\end{abstract}

Kata Kunci: etnopedagogi, mitigasi bencana, pendidikan, sekolah dasar

\section{Pendahuluan}

Rencana Pembangunan Jangka Panjang Nasional (RPJPN) Periode 2005-2025, ditegaskan Visi pembangunan nasional adalah: "mewujudkan manusia dan masyarakat yang mandiri, maju, adil dan makmur". Bangsa yang "mandiri" diukur dari kapasitasnya dalam mewujudkan kualitas hidup dan kehidupan yang sejajar dan sederajat dengan bangsa lain dengan mengandalkan pada kekuatan sendiri. Masyarakat Indonesia yang "maju" diukur dari kualitas manusianya yang dapat mewujudkan keadilan dan kemakmuran yang tercermin dalam system dan kelembagaan ekonomi, social, politik, dan hukum. Manusia dan masyarakat Indonesia yang berkeadilan dapat ditunjukkan dengan struktur dan mekanisme dalam mencegah berbagai nilai, perilaku, masyarakat, maupun antarwilayah, sedangkan "makmur" dapat diukur dari terpenuhinya seluruh kebutuhan hidup berkelanjutan. (Suryadi, 2014).

Untuk memenuhi visi pembangunaan nasional membutuhkan sumber daya yang berkualitas. Sumber daya yang berkualitas dapat dibentuk hanya dalam pendidikan. Peningkatan kualitas sumber daya manusia merupakan priotas utama untuk mewujudkan manusia dan masyarakat Indonesia yang memiliki karakter dan kepribadian serta memiliki kemampuan menguasai cabang-cabang ilmu pengetahuan, teknologi, dan seni untuk memperkuat daya saing perekonomian global.
Menurut Hayat \& Yusuf (2015), kebijakan pendidikan telah bergeser dari input-oriented yang memandang peningkatan mutu pendidikan dilakukan dengan sematamata meningkatkan mutu masukan pendidikan - ke outcome-based yang melihat bahwa mutu pendidikan harus dimulai dengan expected outcome yang jelas dari suatu lembaga pendidikan. Perbaikan dan peningkatan mutu masukan dan proses pendidikan harus merupakan upaya penjabaran untuk mencapai expented outcome. Oleh karena itu, standarisasi expected outcome dalam bentuk kompetensi menjadi titik awal untuk standarisasi masukan dan proses pendidikan. Dalam globalisasi, terutama dalam pasar kerja, telah terjadi mutual recognition antarnegara tentang kualifikasi lulusan atau outcome sehingga meniscayakan adannya proses nasionalisasi dan transnasinalisasi kompetensi lulusan lembaga pendidikan. Kompetensi lulusan ini bergeser dari local specific ke global universal sebagai survival kit untuk dapat bertahan di era mendatang

Dengan demikian, selain kompetensi yang bersifat global, pendidikan dalam pendekatan literasi juga harus menimbang kearifan lokal. Undang-Undang Sisdiknas (UU 20/2003) sebenarnya juga menggariskan paradigma baru ini dalam pendidikan kita, yaitu pendidikan yang berbasis keunggulan lokal untuk mendorong percepatan pembangunan di daerah berdasarkan potensi yang relevan dan dimiliki oleh masyarakat lokal. Hal ini tidak saja berkaitan dengan muatan lokal dalam kurikulum (Pasal 37:1), melainkan juga mempersiapkan siswa mengenali potensi daerahnya masing- 
masing sehingga mereka dapat bekerja yang sesuai dengan kebutuhan local karena sifat pendidikannya yang mengarah pada kecakapan hidup dalam timbangan kearifan lokal (Hayat \& Yusuf, 2015).

Wilayah Negara Kesatuan Republik Indonesia (NKRI) merupakan wilayah yang mempunyai keunikan dan keistimewaan yang khas di dunia. Dengan jumlah pulau lebih dari 17.000 buah dan panjang garis pantai lebih dari $80.000 \mathrm{~km}$ merupakan jumlah pulau terbesar dan garis pantai terpanjang di dunia. Dari segi keaneka ragaman hayati menduduki peringkat ketiga setelah Brasilia dan Kolombia. Dari segi kegunungapian merupakan lokasi gunung api yang paling aktif di dunia dan merupakan pertemuan lempeng tektonik di dunia yang berpotensi menimbulkan bencana letusan vulkanik, gempa, dan tsunami. Pada posisi yang demikian Indonesia merupakan wilayah dengan predikat dilalui sabuk api atau ring of fire. Dari predikat tersebut dalam sepuluh tahun terakhir ditandai dengan bencana gempa dan tsunami Aceh (2004), gempa Yogyakarta (2006), Tasikmalaya (2009), Sumatra Barat (2010), gempa dan tsunami Mentawai (2010), tanah longsor Wassior di Papua Barat (2010) dan letusan Gunung Merapi Yogyakarta (2010) yang membawa korban ratusan jiwa dan ratusan triliun rupiah dalam nilai ekonomi. Letusan Gunung Merapi yang tak kunjung reda, makin mempertegas predikat NKRI sebagai negara sabuk api (Suharjo, 2015).

Masyarakat menjadi objek utama saat terjadi bencana, seharusnya masyarakat mempunyai kemampuan untuk mengetahui kerentanan yang ada, sehingga dapat menjadi pelaku (subjek) utama dalam usaha-usaha pengurangan risiko bencana, sehingga kerugian dapat diminimalisir. Hal itu hanya dapat terjadi jika masyarakat mempunyai perencanaan untuk mengurangi risiko bencana dan mempunyai pengetahuan serta mengerti tentang apa yang seharusnya dilakukan pada saat bencana belum terjadi (prabencana), pada saat tanggap darurat, dan pada saat pasca bencana. Pentingnya peningkatan pemahaman dan ketahanan terhadap bencana itu harus ditanamkan kepada masyarakat sekitar, terutama anak di usia dini yang masih belum mengerti tentang hal-hal apa yang harus mereka lakukan saat peristiwa bencana tidak terduga terjadi (Desfandi,2014).

Pendidikan menjadi salah satu sarana yang efektif untuk mengurangi risiko bencana dengan memasukkan materi pelajaran tentang bencana alam sebagai pelajaran wajib bagi setiap siswa di semua tingkatan, terutama di sekolah-sekolah yang berada di wilayah risiko bencana. Kurikulum yang berbasis kearifan lokal, diharapkan dapat diterima dan dapat dengan mudah di pahami oleh siswa.

Berdasarkan rasional diatas, maka tujuan dari tulisan ini adalah pentingnya pendidikan mitigasi bencana berbasis kearifan lokal untuk sekolah dasar .

\section{PEMBAHASAN}

\section{A. Etnopedagogi}

Ide tentang etnopedagogi di Indonesia muncul di kampus UPI melalui pemikiran Alwasilah,et.al (2009) dan Kartadinata (2010) dalam Suratno (2010). Istilah etnopedagogi di UPI menurut Suratno (2010) dapat dipandang sebagai suatu pesan terkait dengan dengan istilah budaya-karakter (aspek etno), dan pendidikan keguruan (aspek pedagogi). Alwasilah, et.al (2009) mengemukakan dalam konteks budaya secara umum, etnopedagogi menaruh perhatian khusus terhadap local genius dan local wisdom dengan mengungkap nilai-nilai budaya Sunda sebagai model awal. Ajip Rosidi (2009) dalam Suratno (2010) mengingatkan bahwa nilai budaya Sunda modern telah berbaur dengan budaya lainnya. Beberapa postulat dikemukakan terkait karakter masyarakat Sunda: hurip, waras, cageur, bageur, bener, pinter, ludeung, silih asah, silih asuh, silih asih, sineger tengah, singer, motekar dan rapekan. Dapat dikatakan bahwa Etnopedagogi memandang pengetahuan atau kearifan lokal (local knowledge, local wisdom) sebagai sumber inovasi dan keterampilan yang dapat diberdayakan demi kesejahteraan masyarakat.

Dalam perspektif hakikat pendidikan, baik Alwasilah maupun Kartadinata memandang bahwa pendidikan tidak terlepas dari aspek sosial dan kultural. Pendidikan bersifat deliberatif dalam arti masyarakat mentransmisikan dan mengabadikan gagasan kehidupan yang baik yang berasal dari kepercayaan masyarakat yang fundamental mengenai hakikat dunia, pengetahuan dan tata nilai . Oleh karena itu, diperlukan reorientasi landasan ilmiah mengenai pendidikan yang hirau terhadap nilai-nilai kemanusiaan, sesuatu yang selama ini luput dari perhatian dikarenakan kurangnya studi tentang landasan budaya pendidikan. Keutamaan pendidikan hendaknya jangan sampai tereduksi menjadi hal-hal yang superficial, sebagaimana terjadi kini pada rezim standarisasi, sehingga mengabaikan tujuan luhur dari pendidikan itu sendiri, yaitu pendidikan yang membudayakan (Suratno, 2010).

Berdasarkan analisis terhadap dimensi budaya dan pendidikan, Alwasilah et al. (2009, dalam Suratno,2010) memandang Etnopedagogi sebagai praktik pendidikan berbasis kearifan local dalam berbagai ranah serta menekankan pengetahuan atau kearifan lokal sebagai sumber inovasi dan keterampilan yang dapat diberdayakan demi kesejahteraan masyarakat, yakni kearifan lokal tersebut terkait dengan bagaimana pengetahuan dihasilkan, disimpan, diterapkan, dikelola dan diwariskan. Etnopedagogi sebagai praktik pendidikan berbasis kearifan lokal nampaknya sejalan dengan temuan Alexander (2000, dalam Suratno, 2010) yang menunjukkan terdapat hubungan yang erat antara pedagogi dengan kehidupan sosial budaya masyarakatnya. Hal demikian juga sejalan dengan pandangan Bernstein (Bernstein \& Solomon, 1999, dalam Suratno, 2010) yang menyatakan"How a society selects, classifies, distributes, transmits and evaluates the educational knowledge it considers to be public, reflects both the distribution of power and principles of social control".

Menurut Suratno (2010) tentang upayanya untuk memposisikan etnopedagogi secara lebih strategis, pertama, etnopedagogi dapat berperan dalam pendidikan berbasis nilai budaya bagi pengajaran dan pembelajaran dalam konteks 
teaching as cultural activity (Stigler \& Hiebert, 1999) dan the culture of teaching. Di sisi lain, etnopedagogi berperan dalam menciptakan secara berantai kader-kader yang memiliki kecerdasan kultural dan konteks pendidikan guru.

Oleh karena diperlukan tindakan untuk mengangkat kembali nilai-nilai kearifan local sebagai sumber inovasi dalam bidang pendidikan berbasis budaya masyarakat lokal, dengan cara melakukan pemberdayaan melalui adaptasi pengetahuan lokal, termasuk reinterpretasi nilai-nilai kearifan lokal, dan revitalisasinya sesuai dengan kondisi kontemporer. Selain itu diperlukan kerjasama yang kuat antara pemerintah daerah, perguruan tinggi dan budayawan untuk revitalisasi nilai-nilai kearifan lokal maupun mengembangkan konsep-konsep akademik, melakukan uji coba model-model etnopedagogi dalam pembelajaran (Anan-Nur, 2010 dalam Sarbaini 2016)

Menurut Klara,dkk,.(2015), "Ethnopedagogy, an integral part of pedagogy, has a problem, a subject, and the result. Pedagogical, although to achieve their goals, ethnopedagogy as an integral branch of knowledge uses components of ethnic culture as a specific means upbringing activities. Thus, there is a pedagogical essence of ethnopedagogy". Ethnopedagogy, merupakan bagian integral dari pedagogi, memiliki masalah, subjek, dan tujuan. Ethnopedagogy sebagai cabang integral dari pengetahuan menggunakan komponen budaya etnis spesifik berarti dalam kegiatan pendidikan. Dengan demikian, ada esensi pedagogis dalam ethnopedagogy.

Dalam etnopedagogi, unsur utama adalah kearifan lokal masyarakat yang diintegrasikan ke dalam pendididikan. Kearifan atau wisdom dapat dipahami sebagai suatu pemahaman kolektif, pengetahuan, dan kebijaksanaan yang mempengaruhi suatu keputusan penyelesaian atau penanggulangan suatu masalah kehidupan. Kearifan dalam hal ini merupakan perwujudan seperangkat pemahaman dan pengetahuan yang mengalami proses perkembangan oleh suatu kelompok masyarakat setempat atau komunitas yang terhimpun dari proses dan pengalaman panjang dalam berinteraksi dalam satu sistem dan dalam satu ikatan hubungan yang saling menguntungkan (Purba, (2002), Muh Aris Marfai, (2012) dalam Suparmini,dkk, 2013 ).

Kearifan lokal merupakan produk budaya pada masa lalu yang dapat secara terus-menerus dijadikan sebagai pegangan hidup serta memiliki sifat bijaksana bernilai baik yang tertanam dalam suatu budaya dan diterapkan oleh seluruh masyarakat setempat (Wagiran, 2011 dalam Rissa,dkk, 2015). Ini berarti bahwa kearifan lokal merupakan bagian dari budaya yang terdapat pada suatu daerah. Tetapi meskipun bernilai budaya lokal tetapi nilai yang terkandung di dalam kearifan lokal dianggap sangat universal atau berlaku secara luas. Jadi, walaupun kearifan lokal hanya dilaksanakan oleh masyarakat setempat dalam lingkup asal kearifan lokal muncul tetapi nilai yang terkandung dalam kearifan lokal tersebut dapat digunakan secara umum (Rissa,dkk, 2015).

Kearifan lokal yang diwujudkan dalam bentuk perilaku adaptif terhadap lingkungan mempunyai peranan penting dalam pengurangan resiko bencana. Kearifan lokal yang berlaku di suatu masyarakat memberikan dampak positif bagi masyarakat dalam menghadapi dan mensikapi bencana yang datang. Kearifan lokal merupakan ekstraksi dari berbagai pengalaman yang bersifat turun temurun dari nenek moyang atau orang-orang terdahulu yang telah mengalami kejadian bencana. (Muh Aris Marfai, 2012 dalam Suparmini,.dkk 2013).

Menurut Marfai dan Khasanah (2008) ;Muh Aris Marfai (2012) dalam Suparmini,.dkk 2013) adaptasi yang dilakukan manusia terhadap lingkungannya termasuk di dalamnya lingkungan fisik dan proses alam seperti terjadinya bencana menunjukkan adanya interelasi antara manusia dan lingkungan. Dalam hubungan yang saling terkait ini perubahan pada suatu komponen akan menyebabkan perubahan lain dan sebaliknya. Dalam konteks ini pendekatan human ecology menekankan atau menunjukkan adanya hubungan saling terkait (interplay) antara lingkungan dan proses-proses fisik yang berlangsung di dalamnya dan sistem-sistemn sosial/budaya. Dalam proses interaksinya dengan lingkungan sekitar kemudian tercipta budaya dan kearifan lokal.

\section{B. Pendidikan mitigasi bencana berbasis kearifan lokal}

Bencana telah menjadi isu pembangunan, karena hasil pembangunan yang telah dirintis puluhan bahkan ratusan tahun dapat musnah atau rusak seketika dengan adanya bencana, perekonomian masyarakat dan negara pun banyak mengalami kemuduran, banyak prasarana dan sarana ekonomi, sosial dan budaya yang rusak. Masyarakat yang terkena bencana seringkali harus menata ulang kehidupannya dari awal, mereka harus pindah ke tempat lain, dan mulai penghidupan di tempat baru .

Dilihat dari potensi bencana yang ada, Indonesia merupakan negara dengan potensi bahaya (hazard potency) yang sangat tinggi. Beberapa potensi tersebut antara lain adalah gempa bumi, tsunami, banjir, letusan gunung api, tanah longsor, angin ribut, kebakaran hutan dan lahan, letusan gunung api. Potensi bencana yang ada di Indonesia dapat dikelompokkan menjadi 2 kelompok utama, yaitu potensi bahaya utama (main hazard) dan potensi bahaya ikutan (collateral hazard). Potensi bahaya utama (main hazard potency) ini dapat dilihat antara lain pada peta potensi bencana gempa di Indonesia yang menunjukkan bahwa Indonesia adalah wilayah dengan zona-zona gempa yang rawan, peta potensi bencana tanah longsor, peta potensi bencana letusan gunung api, peta potensi bencana tsunami, peta potensi bencana banjir, dan lain-lain. Dari indikatorindikator di atas dapat disimpulkan bahwa Indonesia memiliki potensi bahaya utama (main hazard potency) yang tinggi. Hal ini tentunya sangat tidak menguntungkan bagi negara Indonesia (Permendagri No 33 Tahun 2006).

Pendidikan kebencanaan yang dapat dilaksanakan di sekolah dasar adalah mitigasi bencana dengan memanfaatkan kearifan lokal setempat. Mitigasi didefinisikan sebagai : "Upaya yang ditujukan untuk mengurangi dampak dari bencana baik bencana alam, bencana ulah manusia maupun gabungan dari keduanya 
dalam suatu negara atau masyarakat (Permendagri No 33 Tahun 2006). Mitigasi yang diterapkan dalam pembelajaran di sekolah dasar adalah bagaimana siswa mengenal potensi bencana dan mencegah terjadinya bencana alam dengan menggunakan kearifan lokal setempat dimana siswa tersebut berada.

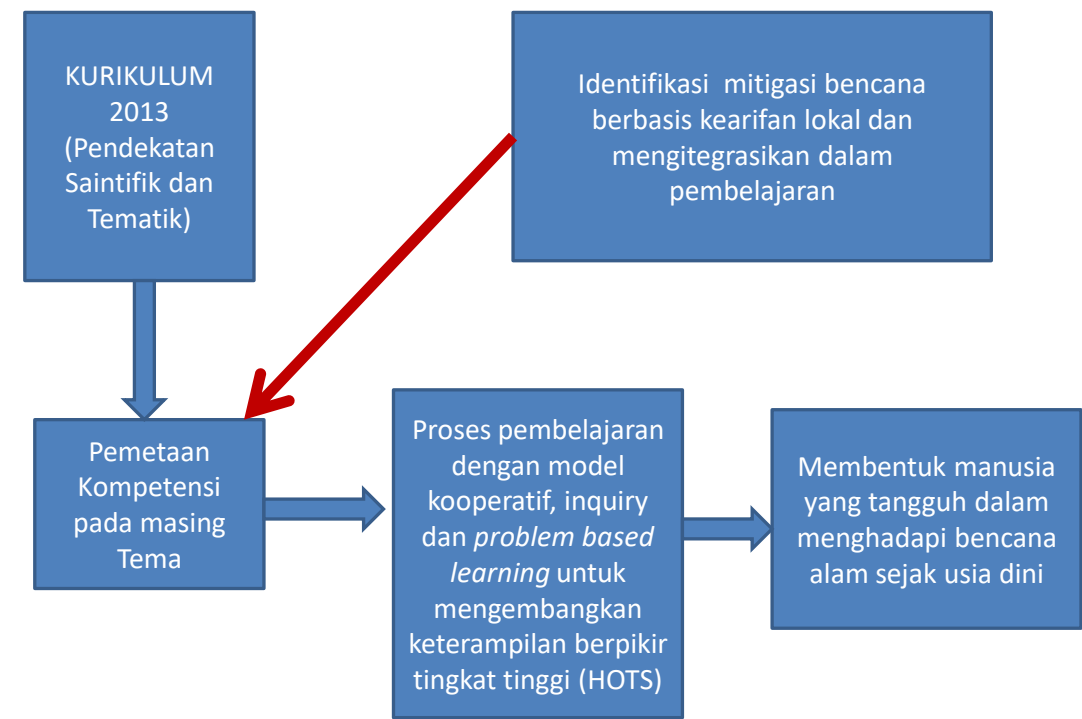

\section{Model pendidikan mitigasi bencana berbasis kearifan lokal}

Terdapat dua langkah dalam menerapkan pendidikan mitigasi bencana di Sekolah dasar, yaitu :

a. Identifikasi kearifan local dalam mitigasi bencana
Indonesia memiliki banyak kearifan lokal dalam mencegah bencana, dikarenakan terdiri dari banyak suku yang mendiami wilayah nusantara ini. Beberapa contoh kearifan lokal di beberapa daerah

\begin{tabular}{|c|c|c|}
\hline No & Daerah & Bentuk kearifan local \\
\hline 1 & Jawa & $\begin{array}{l}\text { Pranoto mongso atau aturan waktu musim digunakan oleh para tani pedesaan yang didasarkan } \\
\text { pada naluri dari leluhur dan dipakai sebagai patokan untuk mengolah pertanian. Berkaitan } \\
\text { dengan kearifan tradisional maka pranoto mongso ini memberikan arahan kepada petani untuk } \\
\text { bercocok tanam mengikuti tanda-tanda alam dalam mongso yang bersangkutan, tidak } \\
\text { memanfaatkan lahan seenaknya sendiri meskipun sarana prasarana mendukung seperti } \\
\text { misalnya air dan saluran irigasinya. Melalui perhitungan pranoto mongso maka alam dapat } \\
\text { menjaga keseimbangannya. } \\
\text { Nyabuk gunung merupakan cara bercocok tanam dengan membuat teras sawah yang dibentuk } \\
\text { menurut garis kontur. Cara ini banyak dilakukan di lereng bukit Sumbing dan Sindoro. Cara } \\
\text { ini merupakan suatu bentuk konservasi lahan dalam bercocok tanam karena menurut garis } \\
\text { kontur. Hal ini berbeda dengan yang banyak dilakukan di Dieng yang bercocok tanam dengan } \\
\text { membuat teras yang memotong kontur sehingga mempermudah terjadinya longsor. }\end{array}$ \\
\hline 2 & Sulawesi & $\begin{array}{l}\text { Komunitas adat Karampuang dalam mengelola hutan mempunyai cara tersendiri dan menjadi } \\
\text { bagian dari sistem budaya mereka. Hutan merupakan bagian yang tidak terpisahkan dengan } \\
\text { alam dirinya sehingga untuk menjaga keseimbangan ekosistem di dalamnya terdapat aturan- } \\
\text { aturan atau norma-norma tersendiri yang harus dipatuhi oleh semua warga masyarakat. } \\
\text { Komunitas Karampuang masih sangat terikat dan patuh terhadap aturan-aturan adatnya, yang } \\
\text { penuh dengan kepercayaan, pengetahuan dan pandangan kosmologi, berkaitan dengan } \\
\text { pengelolaan dan pemeliharaan lingkungan. Agar tetap terjaga. Dewan Adat karampuang } \\
\text { sebagai symbol penguasa tradisional, sepakat untuk mengelola hutan adat yang ada dengan } \\
\text { menggunakan pengetahuan yang bersumber dari kearifan lokal yang mereka miliki. } \\
\text { Sebagaimana diketahui bahwa masyarakat adat ini masih menyimpan mitos dan pesan leluhur } \\
\text { yang berisi larangan, ajakan, sanksi dalam mengelola hutan mereka.. }\end{array}$ \\
\hline
\end{tabular}




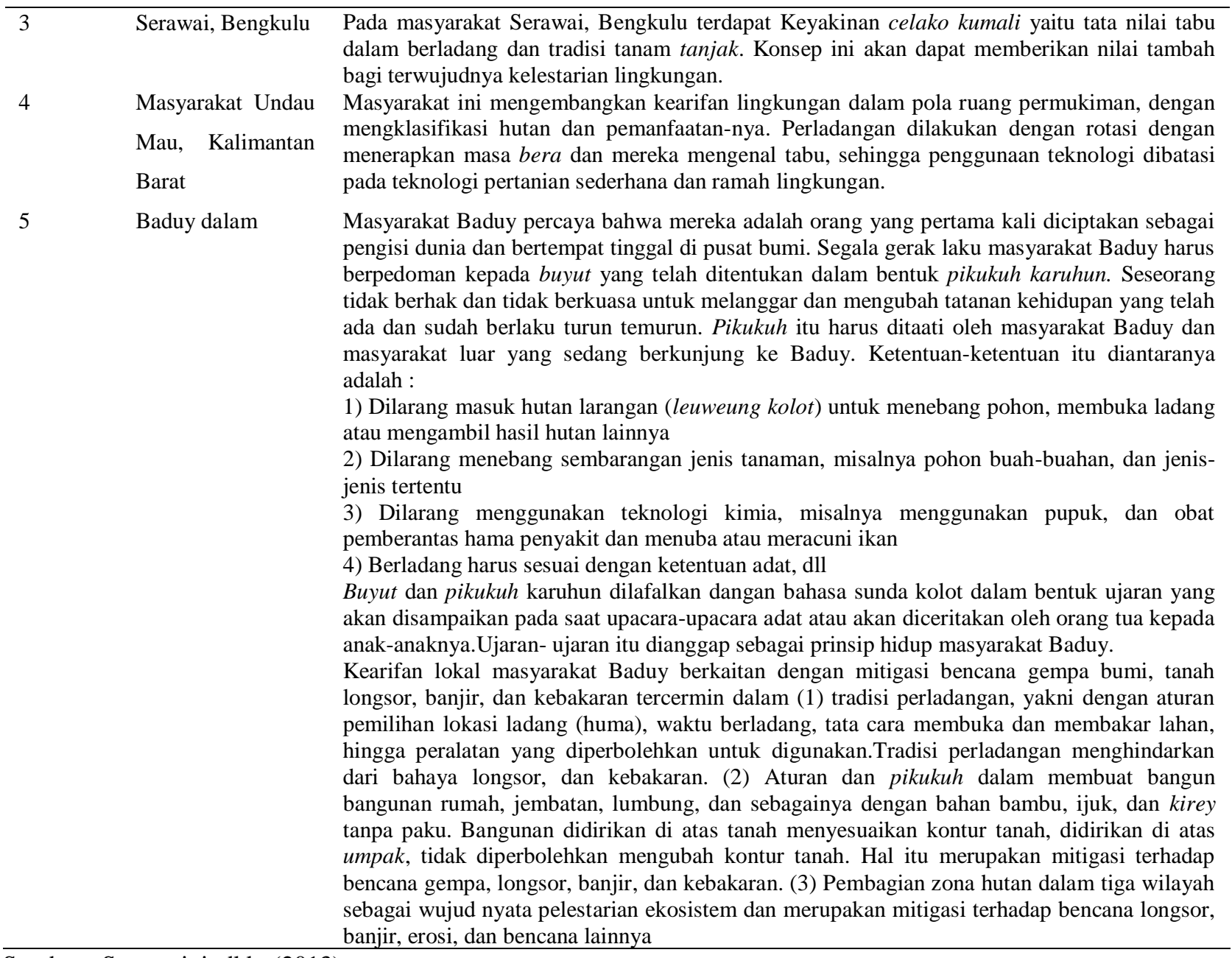

Sumber : Suparmini,.dkk, (2013)

Selain contoh diatas, salah satu bentuk kearifan lokal dalam mitigasi bencana yang terdapat pemukiman di kaki Gunung Merapi yang setiap saat dapat terancam bencana letusan, serta pemukim di pantai yang juga setiap saat dapat terancam bencana gempa dan tsunami dengan kentongan. Kentongan menjadi sangat penting untuk menyampaikan informasi akan datangnya bencana secara cepat dan luas. Sistem ini juga telah teruji, kentongan telah mampu menyampaikan pesan secara sambung-menyambung (tundan) (Suhardjo, 2011).

Smong adalah kearifan lokal masyarakat di Pulau Simeulue dalam membaca fenomena alam pantai telah menyelamatkan banyak masyarakat dari bencana tsunami. Teriakan smong merupakan peringatan dini yang diartikan adanya situasi dimana air laut surut dan masyarakat harus lari ke bukit. Ini adalah pengetahuan yang diperoleh dari leluhur belajar dari kejadian bencana yang pernah terjadi puluhan tahun lalu. Smong ini yang menyelamatkan masyarakat di pulau sangat dekat dengan pusat gempa. Smong bagi masyarakat pulau Simeulue disosialisasikan turun temurun melalui dongeng dan legenda oleh tokoh masyarakat sehingga istilah ini jadi melekat dan membudaya di hati masyarakat pulau itu. Dengan pengetahuan yang dimiliki orang Simeulue banyak masyarakat pesisir pantai lainnya di Aceh terselamatkan saat tsunami terjadi (Resapati W, 2010 dalam Desfandi 2014).

Bentuk lain dari kearifan lokal masyarakat jawa adalah, keengganan orang Jawa untuk menebang pohon besar lebih karena pohon itu ada yang menungggu. Bila ada yang berani menebangnya akan kesambet atau kesurupan. Sikap dan perilaku yang didasari oleh kepercayaan tersebut, bila dikaji secara ilmiah sebetulnya memiliki nilai tinggi dari sudut pandang ekologis. Soalnya keberadaan pohon besar yang tua dan rindang tersebut tidak hanya member keteduhan, menyegarkan (mengubah $\mathrm{CO}_{2}$ menjadi $\mathrm{O}_{2}$ ) mengurangi panas atau temperature udara, dan menahan longsor, tetapi berperan dalam menjaga dan menyerap air (Budihardjo, 2015 dalam Inoguchi., dkk, 2015).

Dengan berbagai contoh bentuk kearifan lokal dalam mitigisi bencana diatas, sebelum diterapkan dalam pembelajaran di kelas perlu diidentifikasi bentuk-bentuk kearifan lokal sesuai dengan daerah atau lokasi siswa tersebut berada. Pada tahap ini guru bersama siswa mengidentifikasi kearifan local dalam mitigasi bencana yang ada di lingkungan siswa. Disinilah peran guru membimbing siswa untuk mengidentifikasi bentuk-bentuk kearifan lokal yang ada di daerahnya. 


\section{b. Mengitegrasikan potensi bencana dan kearifan local dalam mitigasi bencana dalam pembelajaran}

Dalam surat edaran Mendiknas Nomor 70a/MPN/SE/2010 tentang pengarusutamaan pengurangan risiko bencana di sekolah dijelaskan bahwa kebijakan ini menggarisbawahi tiga poin penting dalam implementasi strategi mitigasi bencana di sekolah antara lain: (1) pemberdayaan peran kelembagaan dan kapasitas komunitas sekolah; (2) integrasi Pengurangan Resiko Bencana (PRB) ke dalam kurikulum sekolah; dan (3) pembentukan kemitraan dan jaringan antara beragam pihak guna mendukung implementasi inisiatif PRB di sekolah. Sosialisasi ini dapat dilaksanakan pada kegiatan intrakulikuler yang diintegrasikan dalam beberapa mata pelajaran maupun kegiatan ekstrakurikuler di sekolah dengan berbagai alternatif yang disarankan dalam pedoman pengarusutaman pengurangan resiko bencana. Kurikulum tersebut merupakan kurikulum pendidikan lingkungan hidup dan mitigasi bencana sesuai standar yang ditetapkan BSNP yang diintegrasikan dengan kurikulum yang digunakan oleh sekolah. Porsi peranan pemerintah dalam pelaksanaan kurikulum tersebut yaitu $40 \%$ dari pemerintah pusat dan $60 \%$ dari pemerintah daerah.

Potensi bencana dapat dintegrasikan ke dalam Kurikulum 2013, dengan melihat empat kompetensi inti. Langkah yang dapat dilakukan guru adalah pemetaan kompetensi dasar pada masing-masing tema dan menentukan indikator dengan melihat potensi bencana yang dapat terjadi di wilayah siswa itu berada dan kearifan local dalam mitigasi bencana.

Menurut Shaw.,dkk (2009) "For the prevention of disasters, we should understand disaster mechanisms and locality. We can learn about locality from the community and mechanism from school lectures". Untuk pencegahan bencana, kita harus memahami mekanisme bencana dan wilayah. Kita bisa belajar tentang wilayah dari masyarakat dan mekanisme dari pembelajaran di sekolah.

Pencegahaan bencana dapat dilakukan di sekolah dengan menggunakan kearifan local dari masyarakat setempat. Shaw., dkk (2009) menerapkan model KIDA (Knowledge, Interest, Desire, Action) dalam pendidikan kebencanaan. Knowledge (memberi kesadaran tentang bahaya dan resiko bencana), Interest (menumbuhkan rasa ingin tahu tentang bahaya dan kesiapsiagaan dalam menghadapi bencana), Desire (menjadikan siswa aktif dalam kesiapsiagaan bencana) dan Action (mengambil langkah-langkah yang dipersiapkan dalam menghadapi bencana).

Berdasarkan kajian Selby dan Kagawa (2012), terdapat beberapa pendekatan dalam mengitegrasikan bencana alam ke dalam kurikulum yaitu : 1) The textbook-driven 2) The pilot project approach; 3) The centralized competencybased approach ; 4)The centrally developed special subject (dedicated space) approach; 5) The symbiosis approach dan ; 6)The special event approach. Kurikulum yang berlaku di Indonesia adalah kurikulum 2013. Pada kurikulum 2013 terdapat empat kompetensi inti yaitu : 1) sikap spiritual (menerima dan menjalankan agama yang dianutnya): 2) sikap social (memiliki perilaku jujur, disiplin, tanggung jawab, santun, peduli, dan percaya diri dalam beriteraksi dengan keluarga, teman dan guru); 3) pengetahuan (memahami pengetahuan factual dengan mengamati, mendengar, melihat, membaca dan menanya berdasarkan rasa ingin tahu tentang dirinya, makhluk ciptaan Tuhan dan kegiatanya, dan benda-benda yang dijumpainya di rumah, disekolah dan tempat bermain) ; dan 4) keterampilan (menyajikan pengetahuan factual dalam bahasa yang jelas dan logis, dalam karya yang estetis, dalam gerakan yang mencerminkan perilaku anak beriman dan berakhlak mulia).

Mengintegrasikan kearifan lokal dalam mitigasi bencana pada kurikulum 2013, dapat membentuk sikap spiritual yang tinggi tentang kebesaran Tuhan Yang maha Esa. Hal ini terkait dengan temuan penelitian Adiyoso dan Kanegae (2013), jumlah jawaban yang lebih besar dari anak-anak sekolah terhadap penyebab tsunami menunjukkan bahwa peran agama dalam memahami fenomena alam sangat penting. Dalam mengembangkan materi terkait pengurangan risiko bencana di negara mayoritas Muslim seperti Indonesia, keyakinan bahwa bencana disebabkan karena hukuman Tuhan harus lebih diberikan perhatian. Biar bagaimanapun, keyakinan tersebut tidak akan secara signifkan mempengaruhi pengurangan risiko bencana yang efektif jika orang memiliki kemauan untuk membangun kesiapsiagaan yang tepat. Sangat penting untuk mengembangkan pengetahuan bencana berdasarkan perspektif keagamaan.

Sikap sosial pada siswa akan terbentuk dengan mengitegrasikan kearifan lokal dalam mitigasi bencana. Karena dengan kearifan lokal, siswa menjadi peduli akan pentingnya menjaga lingkungan, pentingnya perilaku disiplin, dan bagaimana beriteraksi dengan teman ketika terjadi bencana.

Pembentukan pengetahuan siswa dengan menggunakan kearifan lokal dalam pembelajaran merupakan salah satu bentuk pendekatan kontekstual. Jhonson (2014), pendekatan kontekstual adalah sebuah proses pendidikan yang bertujuan menolong para siswa melihat makna di dalam materi akademik yang mereka pelajari dengan cara menghubungkan subjek-subjek akademik dengan konteks dalam kehidupan keseharian mereka, yaitu dengan konteks keadaan pribadi, social, dan budaya mereka. Untuk mencapai tujuan ini, system tersebut meliputi delapan komponen berikut: membuat keterkaitan-keterkaitan yang bermakna, melakukan pekerjaan yang berarti, melakukan pembelajaran yang diatur sendiri, melakukan kerja sama, berpikir kritis dan kreatif, membantu individu untuk tumbuh dan berkembang, mencapai standar yang tinggi, dan menggunakan penilaian autentik.

Selain itu pembentukan pengetahuan siswa sangat dipengaruhi berbagai factor yang mencangkup kehidupan manusia. Brofenbrenner dalam Faizah (2008), perkembangan anak dipengaruhi oleh konteks mikro system (keluarga, sekolah dan teman sebaya), konteks mesosistem (hubungan keluarga dan sekolah, sekolah dengan sebaya, dan sebaya dengan individu), konteks ekosistem (latar sosial orang tua dan kebijakan pemerintah), dan konteks 
makrosistem (pengaruh lingkungan budaya, norma, agama, dan lingkungan sosial di mana anak dibesarkan. Kearifan lokal merupakan konteks makrosistem dalam pembentukan pengetahuan siswa.

Mitigasi bencana merupakan bentuk dalam bersikap menghadapi bencana, baik pada saat pencegahan bencana, saat terjadi bencana, dan setelah terjadi bencana. Menurut Adiyoso dan Kanegae (2013), memberikan pengetahuan mengenai bencana dalam program pendidikan bencana bukanlah tugas yang begitu berat. Tantangannya adalah bagaimana program pendidikan bencana dapat mendorong masyarakat untuk memperbarui informasi, meningkatkan tingkat persepsi risiko, menjaga kesadaran, serta melakukan dan memperbarui persiapan yang tepat terhadap bencana di masa mendatang. Sebagai tindak lanjut, perlu dikembangkan berbagai pendekatan pengajaran dan pembelajaran yang akan mampu mencapai tujuan utama dari pengurangan risiko bencana: membuat orang memiliki budaya kesiapsiagaan bencana. Metode ceramah dalam pendekatan pembelajaran akan kurang efektif kecuali didukung oleh metode yang berbeda termasuk simulasi permainan, kunjungan lapangan, percobaan dan pelatihan rutin bencana

Peran guru pada tahap ini adalah mengitegrasikan kearifan lokal dalam mitigasi bencana dalam bentuk bahan ajar atau sumber belajar. Mengintegraisikannya kedalam rencana pelaksanaan pembelajaran yang diawali dengan pemetaan kompetensi inti dan kompetansi dasar yang terdapat pada masing-masing tema. Guru tidak lagi berpatokan pada buku ajar tetapi menggunakan sumber belajar lain yaitu kearifan lokal. Dengan kearifan lokal banyak nilai-nilai yang dapat diajarkan kepada siswa.

\section{KESIMPULAN}

Bencana merupakan anugerah Tuhan Yang Maha Esa, jadi tidak perlu takut dalam menghadapi bencana. Indonesia Negara yang terkurung dalam lingkaran bencana alam dan memiliki banyak suku, ras dan agama sudah barang tentu terdapat banyak kearifan lokal dalam hal mitigasi bencana. Pendidikan adalah proses memanusiakan manusia dengan berbasis budaya.

Kearifan lokal dalam mitigasi bencana alam layak digunakan dalam pembelajaran di Sekolah Dasar dengan mengitegrasikan ke dalam Kurikulum 2013 dengan berbasis tematik dan pendekatan saintifik. Mengitegrasikan kearifan lokal dalam pembelajaran, memberikan suasana belajar yang bermakna. Kebermaknaan yang dimaksud adalah siswa belajar sesuai dengan konteks siswa tersebut berada dan pecapain

Guru dan siswa memiliki peran penting dalam kesiapsiagaan menghadapi bencana, memberikan pengetahuan yang benar tentang bencana kepada masyarakat. Sejak usia dini diajarkan tentang pentingnya mitigasi bencana akan membentuk manusia Indonesia yang tangguh dalam menghadapi bencana alam

\section{DAFTAR PUSTAKA}

Adiyoso, W., Kanegae, H. 2013. Efektifitas Dampak Penerapan Pendidikan Kebencanaan di Sekolah terhadap Kesiapsiagaan Siswa Menghadapi Bencana Tsunami Di Aceh. Indonesia. http://perpustakaan.bappenas.go.id/. diunduh 19 November 2016.

Desfandi, M. 2014. Urgensi Kurikulum Pendidikan Kebencanan Berbasis Kearifan Lokal Di Indonesia http://journal.uinjkt.ac.id/index.php/SOSIOFITK/article/view/1261. Diunduh 24 Desember 2016.

Faizah, D.U. 2008. Keindahan Belajar Dalam Perspektif Pedagogi: Memaknai Pengembangan Dan Pergelutan Masa Inisiatif TK dan Masa Industri di Kelas Awal SD.Cindy Grafika

Hayat, B., Yusuf, S. 2015. Bencmark Internasional Mutu Pendidikan. Jakarta. Bumi Aksara.

Inoguchi, T., Newman, E., Paoletto, G., 2015. Kota Dan Lingkungan Pendekatan Baru Masyarakat Berwawasan Ekologi. Jakarta. LP3ES Indonesia

Johnson, E. B.(2014). Contextual Teaching And Learning: Menjadikan Kegiatan Belajar-Mengajar Mengasyikkan Dan Bermakna. Bandung, Kaifa.

Klara, K., et al. 2015. Ethnic Pedagogy as an Integrative, Developing Branch of Pedagogy. http://www.mcser.org/journal/index.php/mjss/article. Diunduh 25 Desember 2016.

Peraturan Menteri Dalam Negeri No 33 Tahun 2006 Tentang Pedoman Umum Mitigasi Bencana.

Rissa, K.A., Suliyanah., Hasan, S. 2015. Melatih Sikap Tanggap Bencana Siswa Melalui Pembelajaran Yang Mengintegrasikan Nilai Kearifan Lokal . www.google.co.id/. Diunduh 22 Desember 2016.

Sarbaiani. 2016. Pendidikan Berbasis Etnopedagogi :Baiman, Bauntung dan Batuah Eksplorasi Konsepsi dan Konten Pendidikan Urang Banjar. http://eprints.unlam.ac.id/1260/1/2016\%20PROCEEDING\%20SE MINT\%20ETHNOPEDAGOGY\%20NOV,14,2015.pdf. Diunduh 23 Desember 2016

Selby, D., Kagawa, F. 2012. Disaster Risk Reduction In School Curicula: Case Studies From Thirty Countries.https://www.unicef.org/education/files/DRRinCurriculaMapping30countriesFINAL.pdf. Diunduh 23 Desember 2016

Shaw, R.,et al. 2009. 1-2-3 of Disaster Education. www.unisdr.org/files/12088 123sm.pdf. Diunduh 23 Desember 2016.

Suhadrjo, D. 2011. Arti Penting Pendidikan Mitigasi Bencana Dalam Mengurangi Resiko Bencana. http:/download portalgaruda.org. Diunduh 14 Desember 2016

Suparmini., Setyawati., Sumunar, S.R.D. 2013. Mitigasi Bencana Berbasis Kearifan Lokal Masyarakat Baduy. Laporan Penelitian. Universitas Negeri http://eprints.uny.ac.id/24057/1/Laporan\%20PenelitianMitigasi\%20Baduy.pdf. Diunduh 22 Desember 2016.

Suratno, T. 2010. Memaknai Etnopedagogi Sebagai Landasan Pendidikan Guru Di Universitas Pendidikan Indonesia. http://file.upi.edu/Direktori/PROCEEDING/UPIUPSI/2010/Book_3. Diunduh 22 Desember 2016.

Suryadi, A. 2014. Pendidikan Indonesia Menuju 2025 Outlook: Permasalahan, Tantangan \& Alternatif Kebijakan. Bandung. Remaja Rosdakarya Offset. 